\title{
Blind People Voice Based Online Exam
}

\author{
R. Mohanraj, Kanagavalli, Sowmiya Manoj
}

\begin{abstract}
The online examinations are in common for all competitive exams in order to reduce the workload of the faculties as well as students. In conducting online exams, new kind of technologies are using for better functioning. In these areas new implementations are coming. Till date Visually Challenged people cannot attend the online exams due to various factors. To make them to participate in such exams like ordinary peoplean advanced system is proposed. Here the questions which are available as softcopy are being dictated to the students with the help of voice board, the visually challenged peoples can hear it by using headphones. The applicants can answer it by pressing by pressing the keys in the keyboard. [7],[ 9],[11]
\end{abstract}

Keywords : blindness,examination,circuit

\section{INTRODUCTION}

The implementation of internet is becoming more in everywhere and in each sector it has more functioning to do many activities for reducing the working of manpower. we offers a medium that has the potential to be more responsive to students. The students are using the internet fir so many things to improve their knowledge regarding every topic. Now days it became a basic need for everyone to know everything. By knowing all these things, the education system also changed every activity towards students for making their education in better manner. The providing of knowledge in different ways became more common in everywhere. And the learning through the trending technologies will make students to understand in better manner. [1],[3],[5]

As technology growing rapidly, it is necessary to make the things in advanced manner at every aspect of education. In this manner, in the future blind people can also do the online exam like a normal human, if our project is delivered in real time. In this we are using a technology of text to speech area. Although considerable progress has been made in this area, but still there is little effort being put towards improving synthetic voices trained with lower quality of speech. [2 ],[ 4],[6]

In this paper proposing speech enhancement as the process of removing the additive noise. In the real scenario, however speech recordings are contaminated with background noise and reverberation at the same time. By eliminating all these flaws, we are proposing the system for better usage in education system. For making online to available for blind people, we are proposing this paper. The blind people can identify the anything by hearing about that. So, we are

Revised Manuscript Received on August 22, 2019.

R.Mohanraj, Assistant Professor, Department of ECE,Bharath Institute of Higher education and research, Tamilnadu, India

Kanagavalli, Assistant Professor, Department of ECE,Bharath Institute of Higher education and research, Tamilnadu, India

Sowmiya Manoj, Assistant Professor, Department of ECE,Bharath Institute of Higher education and research, Tamilnadu, India

\section{EXISTING SYSTEM}

In Voice recording frameworks the substance had recorded as of now in certain configuration by anybody. The visually impaired individuals ought to should hear the recorded substance in that recording framework by utilizing earphones dependent on along these lines they can without much of a stretch know the substance and learn in a favored manner and furthermore they can connect with that framework by giving their voice as info. This sort of hearing framework will be recorded before directing anything about specific subjects. These basic techniques have been utilized for the visually impaired individuals to uncover their ability in different stages and to get rival ordinary individuals through the assistance of numerous gadgets. The voice condition will be varying at various examples.

\section{DISADVANTAGES}

The real drawback is that they need to give a voice contribution to an unmistakable way that implies anybody needs to record those inquiries by their voice, there might be commotion concealment and furthermore for various dialects other than English they are not feeling great. In the event that the commotion isn't clear, at that point daze individuals can't comprehend that one. Around then, it will be troublesome for them to go to any test. If any mistake happened, there should be one more guy to monitor the exam and he need to give some clarification simultaneously, he has to solve their doubts. The registration will also take so much time.

It is not user friendly and not applicable for all exams. For each exam, each one has to record in different languages. If any mistake happened, it will spoil whole exam. [8],[10],[12]

\section{PROPOSED SYSTEM}

By overcoming all the disadvantages of existing system, a new system is proposed for better use. For loging in RFID is using. In this system, a new keypad having four different buttons will be given to the candidate. The textual content of the questions will be converted to voice signals and will be hear by the candidate through head phone. The voice clarity will be very good in this system. Candidate must choose the response button in the keypad and the result will be stored in the server. If the candidate had not listened, then the candidate can repeat the question again to listen. After they chosen the answer, next question will be displayed. After completing the exam, the results will be shown directly. [14],[ 16], [18] 


\section{Blind People Voice Based Online Exam}

\section{BLOCK DIAGRAM}

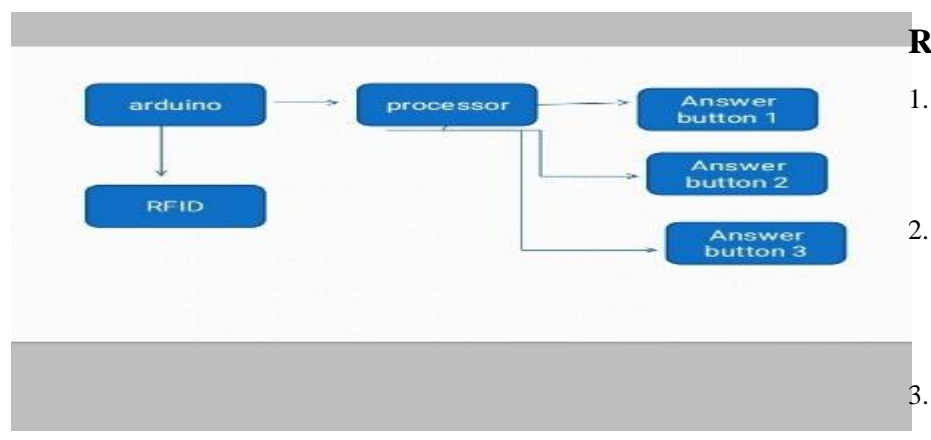

\section{HARDWARE REQUIRED}

ARDUINO: The Arduino UNO is an open source microcontroller board dependent on the microchip ATmega328P microcontroller and created by Arduino. The board is furnished with sets of computerized and simple info/yield sticks that might be interfaced to different development sheets and different circuits.

RFID Reader: RFID Reader is a gadget that utilizes radio recurrence waves to remotely exchange information among itself and a RFID so as to recognize, sort and track resources. RFID Tag: The RFID labels contain electrically put away data. Agreeable labels collect vitality from a close-by RFID peruser's investigating radio waves

\section{MODULE DESCRIPTION}

Speech synthesis: Speech synthesis is a technology used to text to speech conversion.

Speech recognition: Speech recognition is a technology used to speech to text conversion.

\section{WORKING PROCESS}

In this process RFID reader is used for lodging in it is connected to Arduino. After that it is linked with processor. After that questions will be given as input image. This input image is converted into text and then it is converted into voice. The candidate will listen the voice using headphone. When the question has been asked the candidate has to answer the question with the help of buttons. The candidate will choose the require button and it is given to the processor. If the candidate had not properly understood the question the candidate can repeat the question with the help of the repeat button and another button for submit. At last the whole score of the candidate is declared.

\section{CONCLUSION}

This is helpful one for each visually impaired individual to appreciate their ability effectively through online test like different people. In this venture we will go convey a whole application for physically tested individuals which can give intelligent impedance. Examinee can easily give test by giving simple voice directions. Physically tested individuals can undoubtedly give test like a typical man absent much trouble. It is easy to perform the exam without any interruptions. [13], [15], [17]

\section{REFERENCES}

1. Kongkham, D. \& Sundararajan, M. 2019, "Distributed wideband sensing method for faded dynamic spectrum access", International Journal of Innovative Technology and Exploring Engineering, vol. 8, no. 10 , pp. 4309-4312.

2. Balaji, S., John Paul Praveen, A. \& Mohanraj, R. 2019, "Recognizable proof and analysis of palm print in biometric authentication system using bayes techniques", International Journal of Innovative Technology and Exploring Engineering, vol. 8, no. 9 Special Issue 3, pp. 1126-1129.

Kavitha, G., Priya, N., Velvizhi, R. \& Allin Geo, A.V. 2019, "Parallel computation in correspondence and signal processing", International Journal of Innovative Technology and Exploring Engineering, vol. 8, no. 9 Special Issue 3, pp. 1136-1139.

4. Hema, R., Sundararajan, M. \& Balaji, S. 2019, "Smartphone control robot with automatic firing gun", International Journal of Innovative Technology and Exploring Engineering, vol. 8, no. 9 Special Issue 3, pp. 625-627.

5. Kaliyamurthie, K.P., Sundar Raj, B., Velvizhi, R. \& Shanmugapriya, K. 2019, "Dual band paper substrate CPW antenna for wireless applications", International Journal of Innovative Technology and Exploring Engineering, vol. 8, no. 9 Special Issue 3, pp. 605-608.

6. Geo, A.V.A., Arunachalam, A.R., Michael, G. \& Elankavi, R. 2019 , "Evaluating architecture using compact modalities", International Journal of Innovative Technology and Exploring Engineering, vol. 8, no. 9 Special Issue 3, pp. 836-838.

7. Theivasigamani, S., Jeyapriya, D. \& Anita Davamani, K. 2019, "Anamoly analyzing and exploring for wireless sensor networks", International Journal of Innovative Technology and Exploring Engineering, vol. 8, no. 9 Special Issue 3, pp. 1116-1118.

8. Jeyapriya, D., Theivasigamani, S., Velvizhi, R. \& Nandhini, P. 2019, "Program detection in wireless feeler networks", International Journal of Innovative Technology and Exploring Engineering, vol. 8, no. 9 Special Issue 3, pp. 1194-1195.

9. Gowri Sankaran, B., Karthik, B. \& Vijayaragavan, S.P. 2019, "Image compression utilizing wavelet transform", International Journal of Innovative Technology and Exploring Engineering, vol. 8, no. 10, pp. 4305-4308.

10. Gowri Sankaran, B., Karthik, B. \& Vijayaragavan, S.P. 2019, "Weight ward change region plummeting change for square based image huffman coding", International Journal of Innovative Technology and Exploring Engineering, vol. 8, no. 10, pp. 4313-4316.

11. Hema, R., Sundararajan, M. \& Balaji, S. 2019, "Smartphone control robot with automatic firing gun", International Journal of Innovative Technology and Exploring Engineering, vol. 8, no. 9 Special Issue 3, pp. 625-627.

12. Rangaswamy, K. \& Rajabhushanam, C. 2019, "Congestion control in wireless network using TCP friendly rate control (TFRC)", International Journal of Recent Technology and Engineering, vol. 8, no. 2 Special issue 3, pp. 1598-1602.

13. Tamil Selvan, S. \& Sundararajan, M. 2019, "Performance Parameters of 3 Value 8t Cntfet Based Sram Cell Design Using H-Spice", International Journal of Recent Technology and Engineering, vol. 8 , no. 2 Special issue 5, pp. 22-27.

14. Vinoth, V.V. \& Kanniga, E. 2019, "Steganographical techniques in hiding text images - system", International Journal of Recent Technology and Engineering, vol. 8, no. 2, pp. 6535-6537.

15. Saravana, S., Balaji, S., Arulselvi, S. \& John Paul Praveen, A. 2019, "Reliable power quality monitoring and protection system", International Journal of Innovative Technology and Exploring Engineering, vol. 8, no. 9 Special Issue 3, pp. 644-645.

16. Sundaramoorthy, A. \& John Wiselin, M.C. 2019, "Single patch antenna with multiple feed", International Journal of Innovative Technology and Exploring Engineering, vol. 8, no. 9, pp. 1743-1747.

17. Velavan, R., Bharanidharan, S. \& Sheeba, B. 2019, "EMF pollution Causes, effects and protection", International Journal of Innovative Technology and Exploring Engineering, vol. 8, no. 9 Special Issue 3, pp. 1166-1168.

18. Veer, R.A., Arulselvi, S. \& Karthik, B. 2019, "Construction of ensemble square classification approaches in MIMO OFDM", International Journal of Engineering and Advanced 
19. Agitha, W. \& Kaliyamurthie, K.P. 2019, "Improved energy efficient in WBAN using MAC with cloud computing", International Journal of Innovative Technology and Exploring Engineering, vol. 8, no. 8, pp. 2405-2408.

20. Kastro, G.G. \& Wiselin, M.C.J. 2019, "Design and analysis of stub loaded resonator", International Journal of Recent Technology and Engineering, vol. 8, no. 1 Special Issue4, pp. 272-283.

\section{AUTHORS PROFILE}

R.Mohanraj, Assistant Professor, Department of ECE,Bharath Institute of Higher education and research, Tamilnadu, India

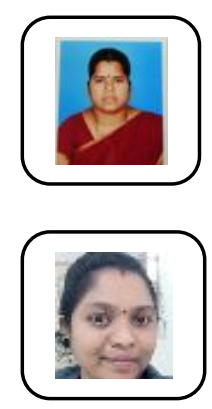

Kanagavalli, Assistant Professor, Department of ECE,Bharath Institute of Higher education and research, Tamilnadu, India

Sowmiya Manoj, Assistant Professor ,Department of ECE,Bharath Institute of Higher education and research, Tamilnadu, India 